Feasting in the Archaeology and Texts of the Bible and the Ancient Near East 



\section{Feasting \\ in the Archaeology and Texts of the Bible and the \\ Ancient Near East}

Edited by

Peter Altmann and Janling Fu

Winona Lake, Indiana

EISENBRAUNS

2014 
Copyright (C) 2014 Eisenbrauns

All rights reserved.

Printed in the United States of America.

www.eisenbrauns.com

\section{Library of Congress Cataloging-in-Publication Data}

Feasting in the archaeology and texts of the Bible and the ancient Near

East / edited by Peter Altmann and Janling Fu.

pages $\mathrm{cm}$

Includes bibliographical references and indexes.

ISBN 978-1-57506-323-2 (paperback : alk. paper)

1. Fasts and feasts-Judaism-History. 2. Bible. Old TestamentCriticism, interpretation, etc. 3. Middle Eastern literature-History and criticism. I. Altmann, Peter, editor. II. Fu, Janling, editor.

BM690.F394 2014

221.8'39412--dc23

The paper used in this publication meets the minimum requirements of the American National Standard for Information Sciences-Permanence of Paper for Printed Library Materials, ANSI Z39.48-1984. @TM 